\title{
THE RESPONSIBILITY OF THE SURABAYA CITY GOVERNMENT TOWARDS PEOPLE WITH MENTAL DISORDERS
}

\author{
St. Ika Noerwulan Fraja \\ Universitas Airlangga, Surabaya, Indonesia \\ Email: stikanoerwulanf@gmail.com
}

\begin{abstract}
The local government is one of the parties responsible for the efforts to cure people with mental disorders. Healing efforts are carried out by health workers and must continue to respect the rights of people with mental disorders and provide good health service facilities. Besides having the right to receive treatment and care, they also have the right to receive rehabilitation, even if they do not have a family or a caregiver. The research problem in this study is about the authority of local government towards people with mental disorders. The purpose of this study was to analyze the authority of local governments towards people with mental disorders and the obstacles they face. This research is a legal research with primary, secondary, and tertiary legal materials that are collected using the literature study method and analyzed by the prescriptive method. The authority of the regional government to regulate it is intended to fulfill the rights of people with mental disorders in terms of health services and adequate facilities. even if the person with mental disorders does not have a family or a caregiver.
\end{abstract}

\section{Keywords: Local government; people; mental disorders; sufferer rights}

\section{Introduction}

The human rights mentioned in Article 1 Number 1 of Law Number 39 Year 1999 concerning Human Rights (hereinafter referred to as the Human Rights Law) are a set of rights inherent in the nature and existence of humans as God's Creatures. It is a gift that must be respected, upheld, protected by the state, law, government, and everyone for the honor and protection of human dignity.

Jan Materson from the United Nations Commission on Human Rights (UNCHR) said that human rights are rights inherent in humans, where if this right is not owned by humans then it is impossible for them to live as humans. And according to Peter R. Baehr, human rights are basic rights that are absolutely necessary for individual development. This view refers to the initial statement of the memorandum of human rights and foreign policy announced by the Dutch foreign ministry in 1979 (Djaali, 2003). 
It should be admitted that basically the definition of human rights is still causing debate here and there. However, it is clear that human rights are divided into several parts:

1. Human rights that are born from the gift of God which cannot be denied, such as the right to life and other human rights that come from God.

2. Human rights that originate from the State granting them with or without the law, such as the right to education, decent living, and so on. (Khairazi, 2015)

State Law Number 36 of 2009 concerning Health Article 149 paragraph (2) which states that "the government, local governments and communities are obliged to carry out medical treatment and care in health care facilities for people with mental disorders who are neglected, homeless, threatening their own safety and / or other people, and / or disturbing public order and / or security". From the statement of Article 149 paragraph (2), we know that treatment and care must be given to people with mental disorders who are neglected, homeless, threatening their safety and / or other people, and / or disturbing public order and / or security. In this article, it is also made clear that one of the administrators of the treatment and care is the regional government.

The legal basis regarding the fulfillment of the rights of people with mental disorders is also contained in Law Number 18 of 2014 concerning Mental Health which strengthens the existing statements in Law Number 36 of 2009 Article 149 paragraph (2).

Law Number 18 of 2014 concerning Mental Health Article 81 states that: (1) The Government and Regional Governments are required to carry out rehabilitation efforts for people with mental disorders who are displaced, homeless, threatening their own safety and / or other people, and / or disturbing order and / or public security. (2) a person with mental disorder who is displaced, stranded, threatens the safety of himself and / or others, and / or disturbs public order and / or security as referred to in subsection (1) includes a person with mental disorder: a. Not capable; b. do not have a family; and / or c. unknown to his family. The content of the above law supports Article 149 paragraph (2) in Law Number 36 Year 2009 regarding Health. Based on the clearly stated articles, it can be concluded that the regional 
government is responsible for the rights of people with mental disorders, including the right to get treatment, care and rehabilitation.

Many people with mental disorders in the city of Surabaya, but not all people with mental disorders are residents of the city of Surabaya, some of them come from outside the city of Surabaya. The handling of people with mental disorders in the city of Surabaya is carried out by the social department and the health department. In carrying out the control they are assisted by the Civil Service Police Unit. Various efforts have been made by the Surabaya government to deal with people with mental disorders, but there are still many of them roaming the streets, neglected and homeless.

Based on the description above, the problems that can be arranged are as follows:

1. The Authority of Local Government in Handling People with Mental Disorders in Surabaya.

2. Constraints Faced by the Surabaya City Government in Handling People with Mental Disorders.

Research purposes are declared as follow:

1. To find out the authority of the local government in handling people with mental disorders in Surabaya.

2. To find out the Constraints Faced by the Surabaya City Government in Handling People with Mental Disorders.

\section{Research Methods}

The process of collecting and presenting research data uses a normative juridical approach which is carried out through literature study by examining (especially) secondary data: laws and regulations, other legal documents, research results, assessment results, and other references.

\section{Review of Related Literatures}

\section{Definition of Legal Responsibility}

According to the Indonesian Main Dictionary (called as KBBI in Indonesian language,) responsibility is the obligation to bear everything, if anything happens, it can be prosecuted, blamed, and sued. In the legal dictionary, responsibility is a necessity for someone to do what has been obliged to him. Furthermore, according to the Quarterly Point, the accountability must have a basis, it is something that causes 
a legal right for one person to sue another, at the same time in the form of things that give rise to a legal obligation for others to give accountability. (Triwulan, 2010)

\section{Definition of Local Government}

The term local government is used to refer to a government unit under the central government which has self-governing authority. State Law No. 23/2014 on Regional Government states that "Regional Government is the regional head as an element of Regional Government administering who leads the implementation of government affairs which fall under the authority of autonomous regions". Regional government is the governor, regent or mayor and regional apparatuses as an element of regional government administration.

Article 18 of the 1945 Constitution of the Republic of Indonesia states that:

1) The Unitary State of the Indonesian Province is divided into regions and the province is divided into districts and cities, each of which has a regional government, which is regulated by law.

2) Provincial, regency, and municipal governments manage their own government affairs according to the principles of autonomy and assistance tasks.

3) Provincial, district, and municipal governments have Regional People's Representative Council whose members are elected through general elections.

4) Governors, Regents and Mayors respectively as heads of democratically elected provincial, district and city governments.

5) The regional government exercises the widest possible autonomy, including governmental affairs which are determined by law as the affairs of the Central Government.

6) The regional government has the right to determine regional regulations and other regulations to carry out autonomy and co-administration.

7) The structure and procedures for operation are regulated in law.

Local government emerged as a consequence of the country's vast territory that it was impossible to administer by the central government. So that state management can be carried out better, a local government or regional government is formed. 


\section{Surabaya City Regional Apparatus Organization}

As stated in the Regional Regulation of the City of Surabaya Number 14 of 2016 concerning the Formation and Composition of the Regional Apparatus of the City of Surabaya and Regulation of the Mayor of Surabaya No. 44 of 2016 concerning Position, Organizational Structure, Description of Duties and Functions, and Administration of the Regional Secretariat of the City of Surabaya.The Regional Secretariat is a Regional Apparatus Organization led by a Regional Secretary who is assisted by:

1. Government Assistant;

2. Assistant for Economy and Development;

3. Assistant for General Administration;

Main Duties and Functions of the Regional Secretariat

The Regional Secretariat has the task of assisting the Mayor in formulating policies and coordinating administration in the implementation of Regional Apparatus duties and administrative services.

In carrying out its duties, the Regional Secretariat has the following functions:

a. Coordinating the formulation of Regional policies;

b. Coordinating the implementation of Regional Apparatus duties;

c. Monitoring and evaluating the implementation of Regional policies;

d. Fostering administration and State Civil Apparatus in regional agencies; and

e. The implementation of other functions given by the Mayor related to his duties and functions.

Government Assistant, supervise:

a. Government Administration and Regional Autonomy Section;

b. Legal section;

c. Organization section.

The Government Assistant has the task of assisting the Regional Secretary in the government sector which includes:

a. formulating policies, monitoring and evaluating the implementation of government affairs which fall under the authority of the regions according to the scope of their duties;

b. Coordinating the implementation of programs and administrative services for regional apparatus according to the scope of their duties. 
Assistant for Economy and Development:
a. Regional Economic and Business Administration Section;
b. Development Administration Section;
c. Cooperation Administration Section.

The Government Assistant has the task of assisting the Regional Secretary in the field of government which includes:

a. Carrying out the formulation of policies, monitoring and evaluating the implementation of government affairs which are under the authority of the Regional government.

b. Coordinating the implementation of programs and administrative services for regional apparatus according to the scope of their duties.

Assistant for Economy and Development:

a. General and Protocol Section;

b. Assets Procurement and Management Services Section;

c. Public Relations Section;

d. People's Welfare Administration Section

The General Administrative Assistant has the task of assisting the Regional Secretary in the field of General Administration which includes:

a. Carrying out the formulation of policies, monitoring and evaluating the implementation of government affairs which are under the authority of the Regional government;

b. Coordinating the implementation of programs and administrative services for regional apparatus according to the scope of their duties.

Law Number 23 of 2014 concerning Regional Government explains that "regional government is the administration of government affairs by the regional government and regional people's representative councils according to the principle of autonomy and co-administration with the broadest possible principle of autonomy in the system and principles of the Unitary State of the Republic of Indonesia". Regional government is run by the Regional Government, where the Regional Government in a Province is the Governor / Mayor and the Regional Apparatus as elements of government administration. Understanding this local government will be 
easier if we do simplify the notion of regional government as government that exists in the region which consists of elements of government regions and elements of the Regional People's Representative Council (DPRD). Meanwhile, in carrying out local government, it must guided by the principle of autonomy and duty of assistance (Fauzan, 2017).

\section{Definition of Mental Disorders}

Mental disorders are a deviation of a person's thought processes, feelings and behavior. According to Stuard and Sudeen, "mental disorder is a disease with manifestations and / or psychological or behavioral disabilities caused by disturbances in social, psychological, genetic, physical, / chemical or biological functions" (Thong, 2011).

Meanwhile, according to State Law Number 18 of 2014 states that "people with mental disorders are people who experience disorders in their thoughts, behavior and feelings which are manifested in the form of several symptoms and / or significant changes in behavior, and can cause suffering and obstacles in carry out the functions of people as humans. Mental disorders are caused by three factors. The following is an explanation of these three factors. (Kartono, 2014).

1) Organic or Physical Factors. Physical diseases, especially those that cannot be cured and result in damage to the brain's nervous system, inevitably result in the form of disturbances and character changes with ametic symptoms, behavioral abnormalities, dementia processes and decreased or loss of consciousness.

2) Psychic factors and personality structure. Psychic disorders in the form of neuroses, psychoses and psychopaths are the extremities of temperaments. Psychic inheritance factors can be both genetic and psychological. Genetic because it is an inherited psychic constitution and is closely related to the physical / physical constitution, so there is a hereditary factor. Meanwhile, psychic occurs when the experiences suffered by the individual become psychotraumatic events that give rise to psychotic decompensation in the individual, with a weak and unstable psychological disposition. Psychiatric disorders experienced by a person also depends on his personality type. In amorphous and apathic type personalities, the typical symptoms of psychological disorders almost never appear, on the contrary, the nerve types tend to be hysterical, neurasthenic and 
hypochondical. This is due to the nature of its temperament with reactive mechanisms and the inclusion of experiences that are typically wrong and lead to pathology.

3) Social Factors

a. Family factor. The most important social factor that gives a psychotic presdisposional influence on children and young people is the family, the forms of the family include: a) Families with fathers and mothers who are unable to function as educators. b) The non-functioning of the family institution as a psycho-social institution.

b. Socio-cultural factors. These environmental, cultural and social conditions influence each other and often lead to stressful and difficult situations for humans. This modern culture which is full of rivalries and competition for life is an explosive culture or a high tension culture, namely a culture full of explosions and tensions. This is caused by people competing for commercial profits and so on. If the ambition to achieve the luxury of life is not fulfilled, people feel ashamed, afraid, anxious, confused, inferior and experience a lot of frustration.

\section{Discussions}

1. The authority of the Regional Government in handling people with mental disorders in Surabaya.

The 1945 Indonesian Constitution also have sociological function. it means that this constitution has a very important role in safeguarding and protecting the public against arbitrary actions by the government. This meaning is in line with the objectives of the country as stated in the preamble to the 1945 Constitution of the Republic of Indonesia. In addition, the existence of provisions on human rights also provides a sociological significance (Fauzan, 2013). In Government Regulation Number 39 of 2012 concerning the Implementation of Social Welfare in Chapter I concerning General Provisions Article 1 provisions number 1 and 2, it is explained that:

a. The implementation of Social Welfare is a directed, integrated and sustainable effort carried out by the government, regional government and the community in the form of social services to meet the basic needs of every citizen, which includes social rehabilitation, social security, social empowerment and social protection. 
b. Social Welfare is a condition for the fulfillment of the material, spiritual and social needs of the citizens in order to live properly and be able to develop themselves so that they can carry out their social functions.

In provision number 1 , it is explained that the Regional Government is the one that carries out social welfare in the form of social services to meet the basic needs of every citizen, which includes social rehabilitation, social security, social empowerment, and social protection. A person can be categorized as socially prosperous if the material, spiritual, and social needs of citizens are met in order to live properly and be able to develop themselves, so that they can carry out their social functions as described in provision number 2 .

It is further explained in Article 2 in the Government Regulation of the Republic of Indonesia Number 39 of 2012 concerning the Implementation of Social Welfare states that:

(1) The implementation of Social Welfare is aimed at:

a. individual;

b. family;

c. group; and / or

d. public citizens.

(2) The implementation of Social Welfare as referred to in paragraph (1) shall be prioritized for those who have a life that is not humanly worthy and have criteria of social problems:

a. poverty;

b. neglectness;

c. disability;

d. remoteness;

e. social disabilities and behavioral deviations;

f. disaster victims; and / or

g. victims of violence, exploitation and discrimination.

The provision in paragraph (1) states that social welfare can be addressed to individuals and the provision in paragraph (2) describes social problems that are prioritized for obtaining social welfare. In the criteria for social problems, people with mental disorders are included in the criteria for social problems at point c, namely disability, where a person with mental disorders is someone who has a mental 
disability. With this mental disability, a person cannot function properly like normal humans. They need a social service in the form of social rehabilitation.

In the Government Regulation of the Republic of Indonesia Number 39 of 2012 concerning the Implementation of Social Welfare, there is also provision 22 concerning Social Rehabilitation in Chapter II, namely:

Article 4

(1) Social Rehabilitation is intended to restore and develop the ability of a person experiencing social dysfunction in order to carry out his social function properly.

(2) Recovery and development as referred to in paragraph (1) shall be aimed at restoring physical, mental and social functioning, as well as providing and improving skills.

Article 5

(1) Social Rehabilitation can be carried out in a persuasive, motivational, coercive manner, either within the family, community or in social institutions.

(2) Persuasive Social Rehabilitation as referred to paragraph (1) shall be in the form of invitations, suggestions and persuasion with the intention of convincing someone to be willing to be socially rehabilitated.

(3) Social Rehabilitation which is carried out motivatively as referred to paragraph (1) shall be in the form of encouragement, encouragement, praise and / or appreciation so that a person is consciously moved to be socially rehabilitated.

(4) Social Rehabilitation which is carried out coercively as referred to paragraph (1) is in the form of coercive action against someone in the Social Rehabilitation process.

Article 6

(1) Social Rehabilitation is addressed at someone who experiences a condition of poverty, neglectness, disability, isolation, social disability and abuse of behavior and who requires special protection which includes:

a. physically disabled;

b. mentally disabled;

c. physically and mentally disabled;

d. immoral;

e. tramp;

f. beggar;

g. former chronic disease sufferer;

h. ex convict;

i. former narcotics addict;

j. ex psycotic;

k. addicton syndrome psyciotropic users.;

l. people with Human Immunodeficiency Virus / Acquired Immuno Deficiency Syndrome;

$\mathrm{m}$. victims of violence;

n. disaster victims;

o. victims of human trafficking;

p. homeless children; and

q. children with special needs. 
(2) Social rehabilitation aimed at someone other than those referred to paragraph (1) is stipulated by the Minister.

From the articles that have been explained previously, it can be concluded that social rehabilitation is intended to restore and to develop te ability of a person in experiencing social disfunction so that he can carry out his social function properly. Those restoration and development are addressed to restore his function physically, mentally and socially, as well as provide and enhance skills. Social Rehabilitation can be carried out persuasively. In Article 6, which has previously been explained, there are criteria regarding a person receiving social rehabilitation. In these criteria people with mental disorders are included in point b, namely people with mental disabilities, for that they have the right to get social services in the form of social rehabilitation. The one who plays a role in a related area regarding social welfare, especially regarding social rehabilitation, is the social service. Regulation of the Minister of Social Affairs of the Republic of Indonesia Number 14 of 2016 concerning Guidelines for the Nomenclature of Provincial Social Service and Regency / City Regional Social Service provides an understanding that the Social Service is an element of regional government administering in the administration of government affairs in the social sector which is the regional authority.

The State Law Number 36 of 2009 concerning Health articles 147 and 149 states that:

Article 147

(1) The efforts to cure people with mental health disorders are the responsibility of the Government, regional government and the community.

(2) The efforts for healing as referred to paragraph (1) shall be carried out by authorized health personnel and in the right place while respecting the patient's human rights.

(3) To treat sufferers with mental health disorders, special health service facilities that meet the requirements and in accordance with the provisions of laws and regulations are used.

Article 149

(1) People with mental disorders who are neglected, homeless, threatening their own safety and / or other people, and / or disturbing public order and / or security are obliged to receive treatment and care at a health service facility.

(2) The government, regional governments and the public are obliged to carry out medical treatment and care at health service facilities for people with mental disorders who are neglected, homeless, threatening their own 
safety and / or other people, and / or disturbing public order and / or security.

(3) The government and regional governments are responsible for equitable provision of mental health service facilities by involving the active participation of the community.

(4) The responsibility of the Government and local governments as referred to paragraph (2) includes the financing of medical treatment and care for people with mental disorders for the poor.

In article 147, it is stated that the regional government is responsible for the efforts to cure people with mental health disorders. Healing efforts are carried out by health workers and must continue to respect the rights of people with mental disorders with good health care facilities. It is further explained by Article 149 which states that people with mental disorders who are neglected, homeless, threaten their own safety and / or other people, and / or disturb public order and / or security are obliged to get treatment and care at health service facilities. Local government is one of which is obliged to provide medication and care for people with mental disorders.

Local governments are also responsible, including in terms of financing treatment and care for the poor and are responsible for equitable provision of mental health service facilities. The explanation in Articles 147 and 149 is also supported by Article 81 of State Law Number 18 of 2014 concerning Mental Health which states that

(1) The Government and Regional Governments are required to carry out rehabilitation efforts for people with mental disorders who are neglected, homeless, threatening their own safety and / or other people, and / or disturbing public order and / or security

(2) People with mental disorders who are neglected, homeless, threatening their own safety and / or other people, and / or disturbing public order and / or security as referred to paragraph (1) includes people with mental disorders who are: a. poor; b. do not have a family, guardian or caretaker; and / or c. unknown to their family.

In addition to have the right to get treatment and care for people with mental disorders, they also have the right to get rehabilitation. This must also be done by the local government even though the fact is that the family of the sufferer is not known or does not have a family, guardian or caretaker.

2. The Constraints Faced by the Regional Government of Surabaya City in Handling People with Mental Disorders). 
In implementing this policy, of course, there are several problems experienced by the Social Service, the Health Service and also other parties involved in handling mental health. The obstacles experienced include the lack of cooperation. The Social Service is one of the parties that is expected to be able to provide a place for rehabilitation for mental health sufferers, because considering the healing process for mental health sufferers is not only enough with medicine but requires a further stage. those who have family members with psychiatric problems often shut themselves off from the environment, especially if there is lockup. This situation made it difficult for officers to enter and examine the patient. shackling clearly violates human rights. Education about mental health is needed for the local community so that people with mental disorders get their rights. Another obstacle is regarding the shelter that has exceeded its capacity. In the Surabaya shelter, not only people with mental disorders are there, but also homeless people and others too. And the fact is that there are people with mental disorders who are also unknown to their families or do not have a family, guardian or caretaker, which causes the shelter to become overloaded. This is a serious obstacle, and raises the question what if this number continues to grow? And what kind of future design should be done. This needs attention from the Surabaya city government.

\section{Conclusion}

1. The duties and functions of local governments in social welfare efforts are to help meet people's basic needs. Regarding social welfare, especially in the management of people with mental disorders, the social service helps to rehabilitate people with mental disorders. Regarding health, the health office is a responsible institution.

2. The problems that are still experienced in handling people with mental disorders include: first, there is still a lack of cooperation between the Surabaya City Regional Work Units. Second, the lack of medical personnel to handle mental health patients directly. Third, the availability of places that are not sufficient or overloaded.

\section{Suggestion}

1. Local governments should make special regional regulations as a legal umbrella related to the implementation of social welfare and mental health. The Regional 
Government through related Services, namely the Social Service and the Health Service in handling the problems of people with mental disorders, continues to provide assistance in fulfilling the right to treatment, care and rehabilitation by mobilizing all its personnel, facilities and budget.

2. 2 It is expected that there will be a maximum allocation of funds from the Surabaya city government in handling mental health in the terms of providing maximum medical personnel, proper places and so on.

\section{REFERENCES}

Djaali, et. al. (2003). Hak asasi manusia (suatu tinjauan teoritis dan aplikasi). Restu Agung.

Fauzan, Encik Muhammad. (2017). Hukum Tata Negara Indonesia, Malang: Setara Press.

Fauzan, Encik Muhammad. (2013). Fungsi Sosiologis Undang-undang Dasar Negara Republik Indonesia Tahun 1945 Dalam Memenuhi Hak-hak Masyarakat, Jurnal Masalah-Masalah Hukum, 42 (3).

Fauzan, K. (2015). Implementasi demokrasi dan hak asasi manusia di Indonesia, Jurnal Inovatif, $\quad$ VIII(1), 81-82. https://onlinejournal.unja.ac.id/jimih/article/view/2194

Kartono, K. (2014). Patologi sosial 3: gangguan-gangguan kejiwaan. Raja Grafindo Persada.

Soekanto, Soeryono. (1981). Pengantar penelitian hukum. UI Pres.

Sekertariat Daerah Kota Surabaya, (2019). Organisasi Perangkat Daerah Kota

Surabaya. https://surabaya.go.id/id/page/0/8074/sekretariat-daerah.

Thong, D. et. al D (2011).Memanusiakan manusia menata jiwa membangun bangsa.

Gramedia.

Triwulan, T \& Febrian, S. (2010). Perlindungan hukum bagi pasien. Prestasi Pustaka. 